\title{
TASMANIAN BATS: IDENTIFICATION, DISTRIBUTION AND NATURAL HISTORY
}

\author{
by Robert J. Taylor, Mark G. O’Neill and Terry Reardon
}

(with two tables and five text-figures)

TAYLOR, R.J., O’NEILL, M.G. \& REARDON, T., 1987 (30:vi): Tasmanian bats: identification, distribution and natural history. Pap. Proc. R. Soc. Tasm., 121: 109-119. https://doi.org/10.26749/rstpp.121.109 ISSN 0080-4703. Department of Zoology, University of Tasmania, Sandy Bay, Tasmania 7005 (R.J.T. \& M.G.O'N.); and Evolutionary Biology Unit, South Australian Museum, Blacks Road, Gilles Plains, S.A. 5086 (T.R.).

A review of the natural history of bats in Tasmania is presented along with data collected in recent surveys. Recent taxonomic changes affecting the Tasmanian bat species are discussed and a key is provided to allow the identification of Tasmanian bats. The appearance of each species is described and body measurements given. Tasmanian populations do not show a uniform trend of increased size compared with southeast Australian populations. Distribution records are presented along with data on habitat preferences and abundance. The diet, activity patterns, roosting requirements, reproductive cycles and conservation status of the species are also discussed.

Key Words: Tasmania, bats, key, diet, reproduction, conservation status, distribution.

\section{INTRODUCTION}

In the past the study of bats has been hindered by the difficulty of catching and observing them. The recent development of harp traps (Tidemann \& Woodside 1978) has lead to a dramatic increase in the work being conducted on this group of mammals (e.g. Inwards \& Phillips 1982 Tidemann 1982, Churchill et al. 1984). In 1983 the authors began an ecological investigation of Tasmanian bats using these new catching techniques. Some data are available on Tasmanian bats (Green 1965, 1966, 1973, Green \& Rainbird 1984); however our studies pointed to the need to synthesize and update this information. In this paper we provide a key to enable the eight species present in Tasmania to be identified and we review the natural history of these bats, including some new data collected during our studies.

\section{COMPOSITION AND SYSTEMATICS}

The bat fauna of Tasmania is composed of eight species representing four genera, all belonging to the microchiropteran family Vespertilionidae. A further species the grey-headed flying fox Pteropus poliocephalus occasionally reaches the Bass Strait islands (Hall \& Richards 1979) but has not yet been recorded on Tasmania proper. The following summary covers the taxonomic reviews relevant to Tasmanian species and accounts for the nomenclature used in this paper.
Eptesicus vulturnus Thomas, 1914

Originally described by Thomas as Eptesicus pumilus vulturnus, type region Tasmania. Adams et al. (in press) distinguish two species within $E$. vulturnus. One species is an arid inland species and the other, with which Tasmanian specimens are conspecific, has a southern coastal distribution from Adelaide to near Sydney.

\section{Eptesicus regulus Thomas, 1906}

Tasmanian and southeastern mainland specimens are genetically indistinguishable by allozyme electrophoresis (Adams et al. in press).

\section{Eptesicus sagittula}

McKean, Richards and Price, 1978

Adams et al. (in press) distinguish two species within E. sagittula using allozyme electrophoresis. Tasmanian specimens are conspecific with the southern species, which ranges coastally from Adelaide to Brisbane. The northern species is distributed coastally northwards from Newcastle, N.S.W.

\section{Chalinolobus morio Gray, 1841}

Originally described as Scotophilus morio. Type location as Tasmania (fide Iredale \& Troughton 1934). Indistinguishable from mainland specimens on allozyme electrophoresis (Adams $e t$ al. in press). 
Chalinolobus gouldii Gray, 1841

Originally described as Scotophilus gouldii, type locality Launceston, Tasmania. Evidence from morphology (Tidemann 1985) supports the recognition of a single species throughout Australia.

\section{Nyctophilus geoffroyi pacificus Gray, 1831}

Although Tasmanian populations of Nyctophilus geoffroyi tend to be darker and larger than mainland populations most authors agree with Thomas (1915) in recognizing a single subspecies in southeastern Australia.

\section{Nyctophilus timoriensis sherrini Thomas, 1915}

There has been some confusion over the specific identity of the larger species of Nyctophilus in Tasmania. It was originally described from Tasmania as $N$. sherrini, but until 1979 most authors agreed that this form was a subspecies of N. timoriensis (Troughton 1941, Tate 1942, Ride 1970). Hall \& Richards (1979) noted that $N$. gould had been recently collected from Tasmania with the implication that $N$. $t$. sherrini was in fact $N$. gouldi. Subsequent to 1984 authors continued to recognise $N$. gouldi as the correct identity for the large long-eared bats in Tasmania (Green 1983, Richards 1983a, O'Neill 1984, but see Hall 1981). However it appears that Hall \& Richards (1979) based their identification on a specimen of $N$. geoffroyi (Parnaby in press), these being larger than mainland animals.

Koopman (1984), upon examining the type of $N$. sherrini, concluded it was a subspecies of $N$. timoriensis, explaining that confusion with $N$. gouldi probably arose because the type was "somewhat immature" giving rise to the smaller measurements. We have followed Koopman (1984) in recognising $N$. timoriensis as the correct name for the long-eared bat in Tasmania.

Nictophilus timoriensis has a patchy distribution across southern Australia including northern Victoria (Richards 1983b) and is the only species where subspecific level differentiation can be recognized between Tasmania and the mainland.

Falsistrellus tasmaniensis Gould, 1858

Tasmania is the type region of this bat. Until recently known as Pipistrellus tasmaniensis. In a recent taxonomic review of Australian Pipistrellus, Kitchener et al. (1986) made generic distinction between the large southern species and the small northern species. In southern Australia they identified two species, Falsistrellus mckenziei in the west and $F$. tasmaniensis in the east including Tasmania.

\section{APPEARANCE}

Pelage colour can be an important aid in distinguishing species. This is especially so with the genus Eptesicus. In E. vulturnus, the smallest Tasmanian bat, the fur on the dorsal surface is generally mid to dark grey. Ventrally the fur is usually dark grey with a distinct light grey or offwhite tip. Pelage colour in this species is, however, variable and some individuals may have a browner fur and lack the white tips on the ventral hair. From our experience it appears that populations in southern Tasmania may contain a higher percentage of individuals with grey predominating in their pelage than in northern Tasmania. The tragus (an upright flap of skin within the ear) is usually translucent white. This character is, however, also variable with some individuals having a tragus merging in colour with the rest of the ear. The skin over the dorsal surface of the forearm is paler than that of the wing membrane.

Eptesicus regulus has reddish brown dorsal fur with lighter brown fur on the ventral surface. Older animals sometimes lack the reddish tinge to their fur. E. sagittula varies from dark grey brown in smaller individuals to very dark brown or almost black in larger individuals. Neither $E$. regulus nor $E$. sagittula has a white tragus and skin colour on the forearm does not contrast with that of the wing membrane as it does in E. vulturnus.

The two species of Chalinolobus can be differentiated from the other genera by fleshy lobes present at the base of the ear and the corner of the mouth and by the elevated appearance of the forehead. C. morio is smaller than C. gouldii and the fur is a uniform chocolate brown all over. $C$. gouldii is much darker in appearance than $C$. morio having dark brown fur on the back and black fur around the head and shoulders with a slightly lighter brown colouration ventrally.

The two Nyctophilus species are easily recognized by their large ears. The ears are joined over the head and are ribbed posteriorly enabling them to be folded. $N$. geoffroy is smaller than $N$. timoriensis and has a well developed $\mathrm{Y}$-shaped noseleaf. Its fur is light grey-brown dorsally and slightly paler ventrally. In $N$. timoriensis the noseleaf is poorly developed. Its fur is dark brown above and lighter brown below. The colouration of its dorsal fur is similar to that of $N$. geoffroyi but the ventral fur is slightly darker tan.

Falsistrellus tasmaniensis, the largest Tasmanian bat, has long pointed ears with a characteristic notch on the outer margin near the tip. It has reddish brown fur on the dorsal surface and lighter brown fur on the belly. 


\section{TABLE 1}

Forearm lengths ( $\mathrm{mm}$ ) for Tasmanian bat species and for the same species in southeastern Australia.

Significance of the difference between sexes and areas was examined using t-tests.

Tasmania

Southeastern Australia

\begin{tabular}{|c|c|c|c|c|c|c|c|c|c|}
\hline Species & Sex & $\begin{array}{l}\text { Numbers } \\
\text { of } \\
\text { individuals }\end{array}$ & Mean \pm S.D. & Range & $\begin{array}{l}\text { Comparison } \\
\text { of sexes }\end{array}$ & $\begin{array}{c}\text { Numbers } \\
\text { of } \\
\text { individuals }\end{array}$ & Mean \pm S.D. & $\begin{array}{c}\text { Comparison } \\
\text { of sexes }\end{array}$ & $\begin{array}{l}\text { Comparison } \\
\text { of areas }\end{array}$ \\
\hline $\begin{array}{l}\text { Eptesicus } \\
\text { vulturnus }\end{array}$ & $\begin{array}{c}\mathrm{M} \\
\mathrm{F}\end{array}$ & $\begin{array}{l}52 \\
18\end{array}$ & $\begin{array}{l}29.1 \pm 0.7 \\
29.7 \pm 0.6\end{array}$ & $\begin{array}{l}27.2-30.7^{*} \\
28.0-31.7^{*}\end{array}$ & $\mathrm{p}<0.01$ & $\begin{array}{l}29 \\
40\end{array}$ & $\begin{array}{l}28.2 \pm 0.8 \\
29.2 \pm 0.8\end{array}$ & $\mathrm{p}<0.001$ & $\begin{array}{l}\mathrm{p}<0.001 \\
\mathrm{p}<0.5\end{array}$ \\
\hline $\begin{array}{l}\text { Eptesicus } \\
\text { regulus }\end{array}$ & $\begin{array}{c}\mathrm{M} \\
\mathrm{F}\end{array}$ & $\begin{array}{r}79 \\
122\end{array}$ & $\begin{array}{l}32.4 \pm 0.9 \\
33.2 \pm 0.8\end{array}$ & $\begin{array}{l}31.0-34.9 \\
31.5-35.6\end{array}$ & $\mathrm{p}<0.001$ & $\begin{array}{l}33 \\
30\end{array}$ & $\begin{array}{l}32.8 \pm 0.7 \\
34.0 \pm 0.7\end{array}$ & $\mathrm{p}<0.001$ & $\begin{array}{l}\mathrm{p}<0.05 \\
\mathrm{p}<0.001\end{array}$ \\
\hline $\begin{array}{l}\text { Eptesicus } \\
\text { sagittula }\end{array}$ & $\begin{array}{l}\mathrm{M} \\
\mathrm{F}\end{array}$ & $\begin{array}{l}45 \\
22\end{array}$ & $\begin{array}{l}34.9 \pm 0.9 \\
34.7 \pm 0.9\end{array}$ & $\begin{array}{l}32.0-37.0^{*} \\
33.1-36.1^{*}\end{array}$ & N.S. & $\begin{array}{l}29 \\
30\end{array}$ & $\begin{array}{l}35.6 \pm 0.7 \\
36.3 \pm 0.8\end{array}$ & $\mathrm{p}<0.001$ & $\begin{array}{l}\mathrm{p}<0.01 \\
\mathrm{p}<0.001\end{array}$ \\
\hline $\begin{array}{l}\text { Chalinolobus } \\
\text { morio }\end{array}$ & $\begin{array}{c}\mathrm{M} \\
\mathrm{F}\end{array}$ & $\begin{array}{l}91 \\
70\end{array}$ & $\begin{array}{l}40.2 \pm 0.9 \\
41.2 \pm 1.0\end{array}$ & $\begin{array}{l}36.2-42.8 \\
38.6-43.0\end{array}$ & $\mathrm{p}<0.001$ & $\begin{array}{l}30 \\
30\end{array}$ & $\begin{array}{l}38.3 \pm 1.0 \\
39.6 \pm 0.8\end{array}$ & $\mathrm{p}<0.01$ & $\begin{array}{l}\mathrm{p}<0.001 \\
\mathrm{p}<0.001\end{array}$ \\
\hline $\begin{array}{l}\text { Chalinolobus } \\
\text { gouldii }\end{array}$ & $\begin{array}{l}\mathrm{M} \\
\mathrm{F}\end{array}$ & $\begin{array}{l}11 \\
14\end{array}$ & $\begin{array}{l}45.9 \pm 1.3 \\
46.2 \pm 0.9\end{array}$ & $\begin{array}{l}44.0-48.7 \\
45.0-47.5\end{array}$ & N.S. & $\begin{array}{l}33 \\
41\end{array}$ & $\begin{array}{l}47.1 \pm 1.3 \\
47.6 \pm 1.5\end{array}$ & N.S. & $\begin{array}{l}\mathrm{p}<0.01 \\
\mathrm{p}<0.01\end{array}$ \\
\hline $\begin{array}{l}\text { Nyctophilus } \\
\text { geoffroyi }\end{array}$ & $\begin{array}{l}\mathrm{M} \\
\mathrm{F}\end{array}$ & $\begin{array}{l}27 \\
35\end{array}$ & $\begin{array}{l}39.2 \pm 1.3 \\
40.9 \pm 0.7\end{array}$ & $\begin{array}{l}36.5-42.6 \\
39.5-42.4\end{array}$ & $\mathrm{p}<0.001$ & $\begin{array}{l}30 \\
30\end{array}$ & $\begin{array}{l}37.1 \pm 1.0 \\
38.5 \pm 0.8\end{array}$ & $\mathrm{p}<0.001$ & $\begin{array}{l}\mathrm{p}<0.001 \\
\mathrm{p}<0.001\end{array}$ \\
\hline $\begin{array}{r}\text { Nyctophilus } \\
\text { timoriensis }\end{array}$ & $\begin{array}{l}\mathrm{M} \\
\mathrm{F}\end{array}$ & $\begin{array}{l}13 \\
10\end{array}$ & $\begin{array}{l}45.6 \pm 1.0 \\
46.5 \pm 1.0\end{array}$ & $\begin{array}{l}43.9-48.0 \\
44.8-48.0\end{array}$ & N.S. & & & & \\
\hline $\begin{array}{l}\text { Falsistrellus } \\
\text { tasmaniensis }\end{array}$ & $\begin{array}{l}\mathrm{M} \\
\mathrm{F}\end{array}$ & $\begin{array}{r}39 \\
-16\end{array}$ & $\begin{array}{l}49.4 \pm 1.0 \\
49.9 \pm 1.3\end{array}$ & $\begin{array}{l}46.0-51.2 \\
47.4-52.2\end{array}$ & N.S. & $\begin{array}{l}31 \\
10\end{array}$ & $\begin{array}{l}52.1 \pm 1.2 \\
52.1 \pm 1.1\end{array}$ & N.S. & $\begin{array}{l}\mathrm{p}<0.001 \\
\mathrm{p}<0.001\end{array}$ \\
\hline
\end{tabular}

* Maximum or minimum values from Green \& Rainbird (1984) included. 


\section{IDENTIFICATION}

The descriptions given in the previous section have been used in conjunction with data on forearm length (table 1) to provide a dichotomous key which will allow greater ease of identification in the field. Forearm measurements should be taken with vernier calipers as shown in figure 1.

\section{KEY TO BATS OF TASMANIA}

1 Ears long and broad, joined over the head and can be folded ... Nyctophilus (fig. 2C) 2 Ears not joined over head and not capable of being folded, ears if long then not broad 3

2(1) Forearm length $<43 \mathrm{~mm}$; nose leaf welldeveloped (elevated lobe of skin with distinct Y-shaped groove in centre, fig. 3A) ... $N$. geoffroyi

Forearm length $>43 \mathrm{~mm}$; nose leaf not welldeveloped (ridge of skin with a slight central depression, see fig. 3B) ... N. timoriensis

3(1) Fleshy lobes present at base of the ear and at the corner of the mouth ... Chalinolobus (fig. 2A)

No fleshy lobes present at the base of the ear or at the corner of the mouth

4(3) Forearm length $<43.5 \mathrm{~mm}$, fur on dorsal surface is uniformly chocolate brown ... $C$. morio

Forearm length $>43.5 \mathrm{~mm}$, fur on dorsal surface is dark brown tending to black on head and shoulders ... C. gouldii

5(3) Forearm length $<38 \mathrm{~mm}$... Eptesicus (fig. 2B) Forearm length $>38 \mathrm{~mm} \ldots$ Falsistrellus tasmaniensis, fig. 2D)

6(5) Colour of skin on upper forearm distinctly lighter than on wing membrane, forearm length for males is $<31 \mathrm{~mm}$ and for females is $\leq 31.7 \mathrm{~mm}$... E. vulturnus

Colour of skin on upper forearm as for wing membrane, forearm length for males is $\geq 31$ $\mathrm{mm}$ and for females $\geq 31.5 \mathrm{~mm}$

7(6) Fur on dorsal surface usually reddish-brown, forearm length of males $31-35 \mathrm{~mm}$, forearm length of females $31.5-35.6 \mathrm{~mm}$... E. regulus Fur on dorsal surface is usually dark brown or almost black forearm length of males $\geq 32 \mathrm{~mm}$, forearm length for females is $\geq 33 \mathrm{~mm} \ldots E$. sagittula

It should be noted that the three species of Eptesicus cannot always be positively identified from external features alone. Pelage colour varies within species and can overlap in the different species. For example, some E. regulus may lack the

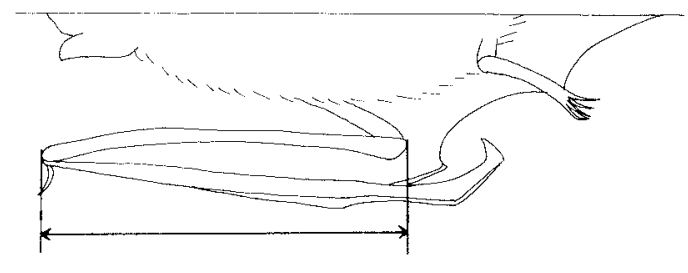

FIG.1 - Diagram showing the method for measuring forearm length.

reddish tinge to their fur and thus look much like $E$. sagittula. Forearm length can usually be used to separate $E$. vulturnus from the other two species as there is only a small overlap $(0.2 \mathrm{~mm})$ between females of $E$. vulturnus and $E$. regulus. E. regulus and $E$. sagittula on the other hand overlap extensively in forearm length. Males of each species can be positively identified by their baculum (a bone in the penis) (fig. 4). Females can be positively identified by a combination of forearm length and skull shape. The braincase of $E$. regulus in side profile has a more flattened appearance than in $E$. vulturnus and E. sagittula (fig. 1 in Green \& Rainbird 1984). Thus E. regulus can be separated from $E$. vulturnus and $E$. sagittula on skull profile and $E$. vulturnus can be separated from $E$. sagittula on forearm length. With experience the profile of the skull can be judged from live specimens by feeling it through the skin and this character can then be used to identify individuals in the field.
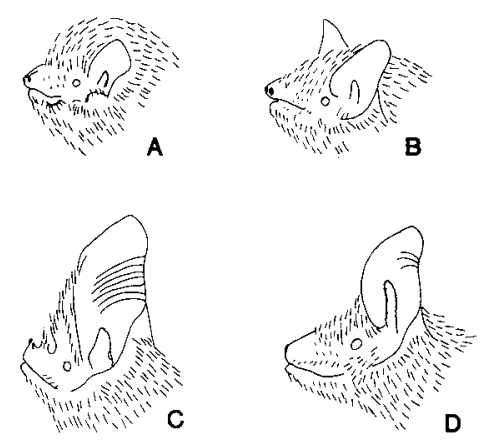

FIG.2 - Profiles showing the facial features of the four genera of Tasmanian bats: $A$ - Chalinolobus, $B-$ Eptesicus, $C-$ Nyctophilus, $D-$ Falsistrellus. 

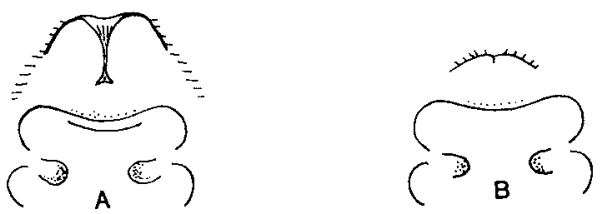

FIG.3 - Nose-leaves of the two species of Nyctophilus in Tasmania. $A-\mathrm{N}$, geoffroyi, $B$ $-\mathrm{N}$. timoriensis.

\section{BODY MEASUREMENTS}

Forearm lengths and weights of adults are presented in tables 1 and 2 . These data were mainly obtained during spring and summer. Weight is influenced by condition and, in females, by reproductive status. Thus lower weights than that given will probably be recorded during winter. Many pregnant females were included in the sample making any comparisons between the sexes difficult. Forearm length gives a better indication of relative size and hence was used to compare the sizes of males and females of each species. Females were significantly larger than males in $E$. vulturnus, $E$. regulus, $C$. morio and $N$. geoffroyi. The mean forearm length for $N$. timoriensis females was larger than that for males but not significantly so ( $p$ $=0.06$ ). It is believed that a large data sample for this species would show females to be significantly larger than males. Data on sexual dimorphism were available for seven of the species from southeastern Australian populations. These data were collected by W. Phillips and S. Inwards in the Brindabella Ranges of the A.C.T. and by C. Tidemann (for most of the E. vulturnus and half of
A

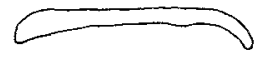

B
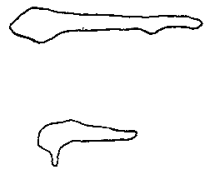
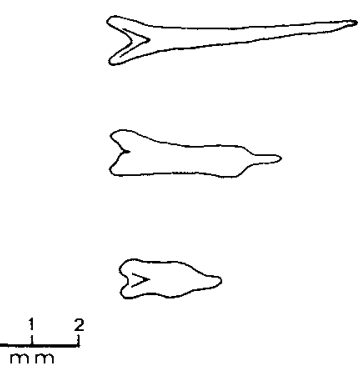

FIG.4 - Side profile (left) and dorsal view of the bacula from the three species of Eptesicus in Tasmania: $A-$ E. vulturnus, $B-$ E. regulus, $C$ -E. sagittula (after McKean et al. 1978). the $C$. gouldii) from the south coast of N.S.W. All of these species except for E. sagittula showed the same trend as that found in Tasmania, i.e. females were significantly larger than males in southeastern Australia. The reason for this difference is not known; we believe the data from southeastern Australia probably reflect the true picture for this species. If this is the case then only the two larger species which are the faster flyers $(N$. timoriensis is a slower flyer according to O'Neill \& Taylor 1986) are not sexually dimorphic. For mammals in general, as body size is reduced, the weight of young produced as a proportion of maternal weight increases (Leitch et al. 1959). Myers (1978) has concluded that sexual dimorphism in vespertilionid bats is correlated with the difficulty of flying with and nourishing a large foetus.

It has been shown for $N$. geoffroyi (Ryan 1963) and for $C$. gouldii (Tidemann 1986) that forearm length increases with latitude. Data from southeastern Australian populations were used to test whether the other species exhibited this increase in size in Tasmania compared with more northern populations. It was found that all species exhibited significant differences in forearm length compared with the southeastern Australian populations (table 1); however some species were smaller in Tasmania. The pattern which emerges appears to be that of a reduction in the size range of species within a genus. Thus, for Eptesicus and Chalinolobus, the smallest species is significantly larger and the largest species is significantly smaller than the mainland populations. The largest Tasmanian bat Falsistrellus tasmaniensis is smaller than the mainland population. The result for $C$. gouldit is contrary to the trend of increasing size with increasing latitude (Tidemann 1986). Our values for $C$. gouldii are similar to those given by Tidemann (1986) for Tasmania but the forearm lengths for the mainland populations are greater than would be predicted from Tidemann's results.

\section{DISTRIBUTION AND HABITAT PREFERENCES}

Figure 5 shows the locations from which each of the eight species have been collected in Tasmania. Our records were obtained during five to ten nights trapping with harp traps at eight sites detailed in O'Neill (1984) and Taylor \& O'Neill (1986) and at a further nine sites using both harp traps and mist nets for usually only one night. Data from trapping by others (see Acknowledgements) at a further seven sites were also available. All other records were obtained from museums and the Tasmanian 
TABLE 2

\section{Weights (g) for Tasmanian bats.}

\begin{tabular}{lccccc} 
Species & Sex & $\begin{array}{c}\text { Number of } \\
\text { individuals }\end{array}$ & Mean \pm S.D. & Range & $\begin{array}{c}\text { Comparison } \\
\text { of sexes }\end{array}$ \\
\hline Eptesicus vulturnus & $\mathrm{M}$ & 51 & $4.1 \pm 0.3$ & $3.7-4.7$ & $\mathrm{p}<0.001$ \\
& $\mathrm{~F}$ & 17 & $4.5 \pm 0.4$ & $3.9-5.6$ & \\
Eptesicus regulus & $\mathrm{M}$ & 77 & $5.0 \pm 0.5$ & $4.1-6.7$ & $\mathrm{p}<0.001$ \\
& $\mathrm{~F}$ & 115 & $5.5 \pm 0.7$ & $3.8-7.7$ & \\
Eptesicus sagittula & $\mathrm{M}$ & 42 & $6.1 \pm 0.6$ & $4.9-7.8$ & $\mathrm{~N} . \mathrm{S}$. \\
& $\mathrm{F}$ & 20 & $6.0 \pm 0.9$ & $4.8-7.6$ & \\
Chalinolobus morio & $\mathrm{M}$ & 90 & $8.9 \pm 0.8$ & $6.7-11.4$ & $\mathrm{p}<0.001$ \\
& $\mathrm{~F}$ & 69 & $10.0 \pm 1.4$ & $7.3-13.7$ & \\
Chalinolobus gouldii & $\mathrm{M}$ & 7 & $14.4 \pm 1.3$ & $12.2-16.2$ & $\mathrm{~N} . \mathrm{S}$. \\
& $\mathrm{F}$ & 9 & $15.0 \pm 1.7$ & $12.9-17.8$ & \\
Nyctophilus geoffroyi & $\mathrm{M}$ & 26 & $8.3 \pm 0.8$ & $6.8-9.9$ & $\mathrm{p}<0.001$ \\
& $\mathrm{~F}$ & 34 & $10.2 \pm 1.0$ & $7.4-12.2$ & \\
Nyctophilus timoriensis & $\mathrm{M}$ & 13 & $12.7 \pm 2.3$ & $9.9-18.9$ & $\mathrm{~N} . \mathrm{S}$. \\
& $\mathrm{F}$ & 10 & $13.1 \pm 1.5$ & $9.8-14.9$ & \\
Falsistrellus tasmaniensis & $\mathrm{M}$ & 32 & $19.4 \pm 1.8$ & $16.2-24.1$ & $\mathrm{p}<0.001$ \\
& $\mathrm{~F}$ & 10 & $21.3 \pm 1.4$ & $19.2-23.5$ & \\
\hline
\end{tabular}

National Parks and Wildlife Service and were mostly for animals at roost sites or that had been found dead. There was a strong bias towards eastern Tasmania in both the trapping locations and the museum records.

There are fewer records for the three larger species ( $N$. timoriensis, $C$. gouldii and $F$. tasmaniensis) than for the others. All species appear to be widely distributed. Eptesicus vulturnus, $C$. gouldii and $N$. timoriensis have not been recorded from southwestern Tasmania, but may be found in this region with more intensive collecting. Nevertheless, species diversity of bats is likely to be lower in southwestern and western Tasmania than in eastern Tasmania. Only $N$. geoffroyi and E. regulus have been recorded around "Melaleuca" in Bathurst Harbour (M. Schulz \& K. Menkhorst, pers. comm.) and four species ( $E$. regulus, $E$. sagittula, $N$. geoffroyi and $C$. morio) have been recorded from rainforest in the Upper Henty River region in western Tasmania (Taylor et al. 1985). By contrast, in forested sites in eastern Tasmania trapping records indicate that it is not uncommon for seven or eight species to occur sympatrically. It is possible that insect populations are not as great in the western and southwestern regions or that the higher rainfall and colder conditions limit the foraging of bats in comparison with eastern Tasmania.

All species have been found in a wide range of forest habitats. Eptesicus vulturnus appears to favour lowland situations. Thus at a coastal dry sclerophyll forest site (elevation $140 \mathrm{~m}$ ) 15 of the 63 Eptesicus captured were E. vulturnus whereas at two other dry sclerophyll forest sites at a higher elevation ( 300 and $460 \mathrm{~m}$ ) only two out of 87 Eptesicus were E. vulturnus. A similar situation occurs in New South Wales where on the south coast $E$. vulturnus is frequently caught (Tidemann 1982) whereas in the Brindabella Ranges near Canberra this species is uncommon above $1000 \mathrm{~m}$ (Phillips \& Inwards pers. comm.). Falsistrellus tasmaniensis and $N$. geoffroyi seem to have adapted to human environments and can be found foraging and roosting in urban and inner-city situations (Maddock 1983, Tasmanian Museum records).

\section{RELATIVE ABUNDANCE}

Data collected from sites where at least five nights trapping had been conducted were used to examine the relative frequencies of capture of each species. Forests sampled were rainforest ( 1 site), blackwood (Acacia melanoxylon) swamps (1 site), 

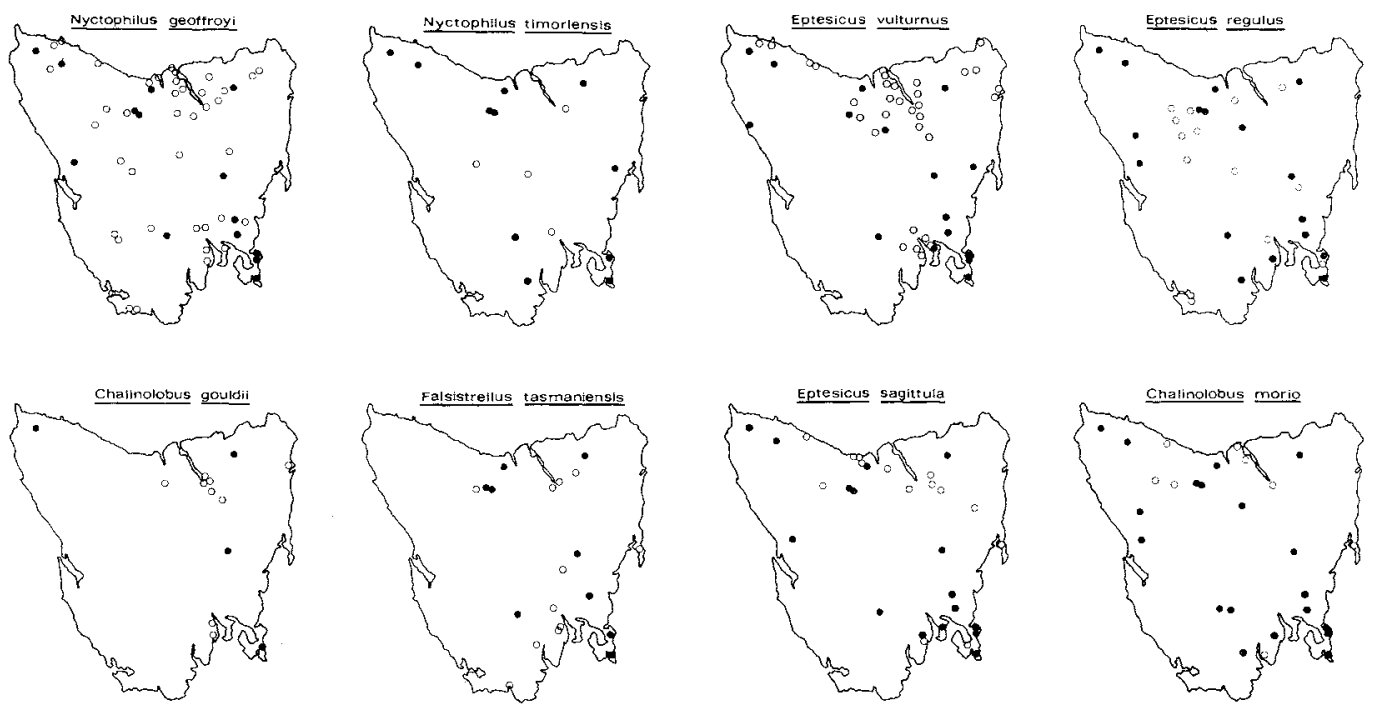

FIG.5 - Locations from which each of the bat species has been collected in Tasmania. Solid circles indicate our records. Open circles indicate records obtained from other sources.

wet sclerophyll ( 2 sites), and various dry sclerophyll types ( 5 sites). These were located in western (1), northwestern (1) and eastern Tasmania (7). Trapping was conducted over the late spring to early autumn period. At one of the wet sclerophyll sites and one of the dry sclerophyll sites, some trapping was carried out over a pond or stream. Normally, however, traps were placed along forestry tracks.

A total of 544 bats were trapped at these sites. The relative proportions of each of the species were: E. vulturnus $11 \%$, E. regulus $35 \%$, E. sagittula $12 \%$, C. morio $20 \%$, C. gouldii $2 \%, N$. geoffroyi $10 \%, N$. tasmaniensis 3\%, $F$. tasmaniensis $7 \%$. Eptesicus regulus was thus the most frequently caught bat. It was three times more abundant than its congeners $E$. vulturnus and $E$. sagittula. The three largest bats, $N$. timoriensis, $C$. gouldii and $F$. tasmaniensis, were caught the least. The proportions of each species trapped cannot be directly translated into relative abundances since trappability probably varies between species (Taylor \& O'Neill 1986). The authors, however, believe it is likely that the larger species are less abundant than the others.

\section{DIET AND FORAGING PATTERNS}

All species are insectivorous. Both $N$. geoffroyi and $N$. timoriensis are known to capture non-volant insects on the ground and from the surface of vegetation(Dwyer 1965, Vestjens \& Hall 1977, O'Neill \& Taylor in press). However, only $N$. timoriensis appears to specialize on non-volant insects. Five of the species ( $E$ vulturnus, E. regulus, $E$. sagittula, $N$. geoffroyi and $C$. morio) feed opportunistically, their diets reflecting local and seasonal variations in insect abundance and diversity. Lepidopterans make most of the diet of these species. The two larger species, $F$. tasmaniensis and C. gouldii, appear to be more selective feeders with coleopterans being the most important item in their diet. The sizes of insects eaten is positively correlated with the size of the bat species (with the exception of C. gouldii) (O'Neill \& Taylor in press).

Species differ in the aerodynamic properties of their wings. This results in differences in their manoeuvrability and flight speed. Flight ability has been found to be related to habitat use with species differing in the height at which they forage and the openness of the vegetation utilized (O'Neill \& Taylor 1986). Nyctophilus geoffroyi and $N$. timoriensis have broad wings allowing extreme manoeuvrability and slow flight. Both species feed close to the ground and, at times, amongst the undergrowth. Eptesicus regulus and E. vulturnus are faster flyers than either of the Nyctophilus species and generally feed around the top of the 
undergrowth. Chalinolobus morio and E. sagitula feed mostly in the middle layers of the forest between the canopy and the understorey. Falsistrellus tasmaniensis and $C$. gouldii have relatively long narrow wings resulting in limited manoeuvrability and fast direct flight. They generally feed in the upper layers of the forest canopy or above it.

\section{ACTIVITY PATTERNS}

All species are nocturnal. During late spring and summer there is usually a bimodal pattern of activity with foraging occurring in the first three hours after dark and the three hours prior to first light in the morning. A marked decrease in activity occurs during the middle of the night ( $O$ 'Neill 1984). This pattern of activity correlates well with changes in the abundance of volant insects ( $O^{\prime}$ Neill 1984). However, considerable variation in activity levels may occur according to sex, age, reproductive condition, season and climatic events (Erkhert 1982). Hibernation occurs between late autumn and early spring. In the Brindabella Ranges near Canberra where seven of the eight Tasmanian species occur sympatrically, it has been found that C. morio enters torpor later and emerges from hibernation earlier than the other species (Phillips \& Inwards 1980). This also appears to be the case in Tasmania (Taylor \& Savva unpubl. data).

\section{ROOSTING REQUIREMENTS}

All Tasmanian bats are primarily tree roosters. However individuals have been found in a remarkable variety of roost types, e.g. roof and wall cavities in buildings, rolled canvas blinds, timber stacks, the exhaust pipe of a tractor and bird nests. There is only one record of the occurrence of bats in caves in Tasmania (Savva \& Taylor 1986). Few data a re a vailable on the type of roosts utilized by bats in trees. Phillips et al. (1985) found male $F$. tasmaniensis utilizing a stem hole on the main trunk of a live Eucalyptus dalrympleana. Lunneyet al. (1985) recorded roosts of C. morio in exceptionally large eucalypts. Two roosts of $E$. sagittula reported to the Tasmanian National Parks and Wildlife Service were in hollows of old eucalypts (D. Rounsevell pers. comm.). Woinarski (1986) found two bats (probably C. gouldii) roosting in the hollow of a stump. Recent results from a study in Tasmania point to the importance of narrow cracks in eucalypts as roost sites for bats (Taylor \& Savva unpubl. data). These can be present under bark, on the trunk or in the rotten heartwood of the bole of the tree. Older trees are more likely to have suitable roost sites. Fire appears to be important in creating roost sites.

It is possible that roosting sites change over the year as microclimate preferences vary in association with seasonal changes in metabolic rate (Dwyer 1964, Ransome 1968). All species are known to roost communally at least some of the time. Males appear to be less selective in their choice of roost site and are more of ten found singly than are females (Tidemann pers. comm.).

\section{REPRODUCTIVE CYCLES}

Observations on the reproductive cycles of Tasmanian bats have been made by Green (1965, 1966 ) on $E$. vulturnus and $N$. geoffroyi and by O'Neill (1984) on E. regulus, E. sagittula and $C$. morio. Studies have also been conducted on several of the species on the mainland, i.e. F. tasmaniensis (Phillips et al. 1985), E. regulus (Kitchener \& Halse 1978), C. morio (Young 1979, Kitchener \& Coster 1981) and C. gouldii (Kitchener 1975). The pattern of reproduction appears to be similar in all species so far studied.

In males spermatogenesis occurs in spring and summer. Sperm are stored in the epididymes as the testes regress. Mating generally occurs in autumn and also occasionally during the hibernation period. However, Green (1965) noted an influx of males into a maternity colony of $E$. vulturnus in late spring after parturition and suggested that post-partum copulation was occurring.

All species are probably monoestrous. Females usually store sperm over the winter and use this to fertilize ova in early spring. Parturition occurs in late spring and early summer but varies with latitude and elevation through the influence of climatic factors on the timing of emergence from hibernation (Kitchener 1975, Phillips \& Inwards 1981). Lactation is usually completed by the end of January or early February. Lactation has been found to finish later in $C$. morio than in the other species in the Brindabella Ranges near Canberra (Phillips \& Inwards pers. comm.) and this is probably also the case in Tasmania (O'Neill 1984). Litter size is usually two in $N$. geoffroyi, $N$. timoriensis and $C$. gouldii and one in the other species (Strahan 1983).

\section{DISCUSSION}

The number of species of bats present in Tasmania is lower than elsewhere in eastern Australia but conforms with a trend of reduced numbers of species with increasing latitude (Hall 
1981). Cave dwelling species are generally less numerous than forest roosting species and show a similar trend of decreasing number of species with increasing latitude (Hall 1981). In southern Australia there are numerous caves which have been poorly colonized by bats (Hall 1981) and it is thus perhaps not surprising that no cave dwelling species occur in Tasmania. All Tasmanian species except $N$. timoriensis occur on the adjacent southeastern mainland. Nyctophilus timoriensis has a patchy distribution across southern Australia including northern Victoria (Richards 1983b).

Contrary to what one might expect from Bergmann's rule, it was found that not all species exhibited a trend of increased size compared with populations from southeastern Australia. However, most of the data for southeastern Australia came from an area where the species are near the elevational limit of their range whereas the Tasmanian data are mostly from populations at lower elevations. Since body size is related to the size of insects eaten (O'Neill \& Taylor in press), it is possible that the apparent contraction of the size range of species in Tasmania is related to a reduction in the size range of the prey available. We have no data on insect populations from southeastern Australia with which to test the hypothesis.

Several of the inferences made about the genus Eptesicus in Tasmania by Green \& Rainbird (1984) (namely on the relative abundance and habitat preferences of the species) have been found to be incorrect. Green \& Rainbird (1984) based their conclusions on evidence from museum collections. These collections tend to give a biased picture because of the predominance of specimens from populated areas. The main problem in undertaking detailed field studies of this genus lies in the difficulty of correctly identifying the three species. Hall \& R ichards (1979) listed the number of colour bands on the ventral hair and the shape of the lobe on the calcaneum as being features which could be used to separate the species in the field. These characters have not proved to be of any use in separating the Tasmanian specimens of this genus. The need to use internal characters for positive separation of the three species would hinder any detailed ecological study where individuals need to be released after capture. Simple antibody tests such as used by Herd (1983) may allow species identification without the need to sacrifice animals.

Our studies have shown that all species are widespread and none are rare. The two most important factors determining the numbers of bats are likely to be the abundance of food and the availability of roost sites. The complete clearing of natural vegetation for agricultural or urban development will probably be the most disruptive factor affecting bat populations. An understanding of the effects of the forest industry on bats is essential due to the large a reas of habitat which are subject to disturbance. Limited forest exploitation may, in fact, be beneficial. We have found that bats were more abundant in a 12 year old regrowth forest than in an equivalent mature dry sclerophyll forest (Taylor \& O'Neill 1986), probably due to a greater abundance of insects in the regrowth forest. However, bats do not appear to roost in regrowth forest and depend on the presence of old mature trees in the surrounding unlogged forest for roost sites (Taylor \& Savva unpubl. data). Thus, in the future if most State forests have been converted to even aged stands, it is likely that bat populations will be severely reduced due to a shortage of suitable roost sites. The lack of preferences for specific vegetation types by Tasmanian bats should, however, act as a buffer against the effects of development in the short-term.

\section{ACKNOWLEDGEMENTS}

We would like to thank Bob Green (Queen Victoria Museum), Phil Andrews and Catherine Medlock (Tasmanian Museum) and Dave Rounsevell (National Parks and Wildlife Service) for access to specimens in their care and allowing the use of their distribution records. N. Savva, R. Rose, D. Woodside and M. Schulz supplied trapping records. W. Phillips, S. Inwards and C. Tidemann provided data on forearm lengths of bats trapped by them in the A.C.T. and the south coast of N.S.W. Staff of the Forestry Commission, especially Dick Chuter and Ken Felton, provided logistical support and information on the location of forest types. Bob (Spider) Mesibov provided welcome hospitality on a northwest field trip. N. Savva and P. Frappell helped with field work. Drs W. Phillips, C. Tidemann and C. Kemper commented on a previous draft of the manuscript. Our research has been funded by the Forest Ecology Research Fund and the Bureau of Flora and Fauna. 


\section{REFERENCES}

ADAMS, M., BAVERSTOCK, P.R., WATTS, C.H.S \& REARDON, T., In press: Electrophoretic resolution of species boundaries in Australian Microchiroptera I. Eptesicus (Chiroptera: Vespertilionidae). Aust. J. Biol. Sci.

CHURCHILL, S.K., HALL, L.S. \& HELMAN, P.M., 1984: Observations on long-eared bats (Vespertilionidae: Nyctophilus) from Northern Australia. Aust. Mammal., 7: 17-28.

DWYER, P.D., 1964: Seasonal changes in activity and weight of Miniopterus schreibersi blepotis (Chiroptera) in northeastern New South Wales. Aust. J. Zool, 12: 52-69.

DWYER, P.D., 1965: Flight patterns of some eastern Australian bats. Vict. Nat., 82: $36-41$.

ERKHERT, H.G., 1982: Ecological aspests of bat activity rhythms. In Kunz, T.H. (Ed.): $E C O L O G Y$ $O F$ BATS. Plenum, New York: 201-242.

GREEN, R.H., 1965: Observations on the little brown bat Eptesicus pumilus Gray in Tasmania. Rec. Queen Vict. Mus., 20: 1-16.

GREEN, R.H., 1966: Notes on the lesser long-eared bat Nyctophilus geoffroyi in northern Tasmania. Rec. Queen Vict. Mus, , 22: 1-4.

GREEN, R.H., 1973: THE MAMMALS OF TAS $M A N I A$. The author, Launceston.

GREEN, R.H., 1983: SKULLS OF THE MAMMALS IN TASMANIA. Queen Victoria Museum and Art Gallery, Launceston.

GREEN, R.H. \& RAINBIRD, J.L., 1984: The bat genus Eptesicus Gray in Tasmania. Tasm. Nat., 76: 1-5

HALL, L.S., 1981: The biogeography of Australian bats. In Keast, A. (Ed.): ECOLOGICAL BIOGEOGRA PHY OF AUSTRALIA. Dr W. Junk, The Hague: 1557-1583.

HALL, L.S. \& RICHARDS, G.C., 1979: BATS OF EASTERNAUSTRALIA. Queensland Museum Booklet No. 12.

HERD, R.M., 1983: A simple antibody test for field identification of morphologically similar mammals. J. Mammal., 64: 700-701.

INWARDS, S.J. \& PHILLIPS, W.R., 1982: Wing morphometrics of some Australian microchiroptera. Bull. Aust. Mamm. Soc., 7: 43.

IREDALE,. T. \& TROUGHTON, E. Le.G., 1934: Check-list of the mammals recorded from Australia. Mem. Aust. Mus., 6: 1-122.

KITCHENER, D.J., 1975: Reproduction in female Gould's wattled bat, Chalinolobus gouldii (Gray) (Vespertilionidae), in Western Australia. Aust. J. Zool., 23: 29-42.

KITCHENER, D.J., CAPUTI, N. \& JONES, B., 1986 Revision of Australo-Papuan Pipistrellus and of Falsistrellus (Microchiroptera: Vespertilionidae). Rec. West. Aust. Mus., 12: 435-495.

KITCHENER, D.J. \& COSTER, P., 1981: Reproduction in female Chalinolobus morio (Gray) (Vespertilionidae) in south-western Australia. Aust. J. Zool., 29: 305-320.
KITCHENER, D.J. \& HALSE, S.A., 1978: Reproduction in female Eptesicus regulus (Thomas) (Vespertilionidae), in south-western Australia, Aust. J. Zool, 26: 257-267.

KOOPMAN, K.F., 1984: Taxonomic and distributional notes on tropical Australian bats. Amer. Mus. Novitates, 2778: 1-48.

LEITCH, I., HYTTEN, F.E. \& BILLEWICZ, W.Z. 1959: The maternal and neonatal weights of some mammalia. Proc. Zool. Soc. Lond., 133: $11-28$.

LUNNEY, D., BARKER, J. \& PRIDDEL, D., 1985: Movements and day roosts of the chocolate wattled bat Chalinolobus morio (Gray) (Microchiroptera: Vespertilionid) in a logged forest. Aust. Mammal., 8: 313-317.

MADDOCK, T.H., 1983: Lesser long-eared bat Nyctophilus geoffroyi. In Strahan, E. (Ed.): COMPLETE BOOK OF AUSTRALIAN MAM$M A L S$. Angus and Robertson, Sydney: 331

McKEAN, J.L. RICHARDS, G.C. \& PRICE, W.J., 1978: A taxonomic appraisal of Eptesicus (Chiroptera: Mammalia) in Australia. Aust. $J$. Zool., 26: 529-537.

MYERS, P., 1978: Sexual dimorphism in size of vespertilionid bats. Amer. Natur., 112: 701-711.

O'NEILL, M.G., 1984: STRUCTURE AND COMPOSITION OF TASMANIAN BAT COMMUNITIES. Unpubl. B.Sc. Honours thesis, University of Tasmania.

O'NEILL, M.G. \& TAYLOR, R.J., 1986: Observations on the flight patterns and foraging behaviour of Tasmanian bats. Aust. Wildl. Res., 13: 427-432.

O'NEILL, M.G. \& TAYLOR, R.J., in press: Feeding ecology of a south temperate bat community. $J$. Anim. Ecol.

PARNABY, H.E., in press: Distribution and taxonomy of the long-eared bats, Nyctophilus gould $i$ Tomes 1858 and Nyclophilus bifax Thomas 1915 (Chiroptera: Vespertilionidae) in eastern Australia. Proc. Linn. Soc. N.S.W.

PHILLIPS, W.R. \& INWARDS, S.J., 1980: Bat ecology study in the A.C.T. Aust. Bat Res. News, 16:4-6.

PHILLIPS, W.R. \& INWARDS, S.J., 1981: The reproductive cycle of Gould's long-eared bat: Nyctophilus gouldi. Bull. Aust. Mamm. Soc., 7(1): 51 .

PHILLIPS, W.R. \& TIDEMANN, C.R., INWARDS, S.J. \& WINDERLICH, S., 1985: The Tasmanian pipistrelle: Pipistrellus tasmaniensis Gould 1858: Annual activity and breeding cycles. Macroderma, 1: 2-11.

RANSOME, R.D., 1968: The distribution of the greater horseshoe bat, Rhinolophus ferrum-equinum, during hibernation, in relation to environmental factors. J. Zool., Lond., 154: 77-112.

RICHARDS, G.C., 1983a: Gould's long-eared bat Nyctophilus gouldi. In Strahan, R. (Ed.): COMPLETE BOOK OF AUSTRALIAN $M A M M A L S$. Angus and Robertson, Sydney: 330. 
RICHARDS, G.C., 1983b: Greater long-eared bat Nyctophilus timoriensis. In Strahan R. (Ed.) COMPLETE BOOK OF AUSTRALIAN $M A M M A L S$. Angus and Robertson, Sydney: 328

RIDE, W.D.L., 1970: A GUIDE TO THE NATIVE MAMMALS OF AUSTRALIA. Oxford University Press, Sydney.

RYAN, R.M., 1963: COLLECTED STUDIES ON MAMMALIAN ECOLOGY AND DISTRIBUTION. Unpubl. M.Sc. thesis, University of Melbourne.

SAVVA, N. \& TAYLOR, R.J., 1986: Bat remains in a Tasmanian cave. Macroderma, 2: 21.

TATE, G.H.H., 1942: Results of the Archbold Expeditions No.47. Review of the vespertilionine bats, with special attention to genera and species of the Archbold collections. Bull. Amer. Mus. Nat. Hist., 80: 221-297.

TAYLOR, R.J., BRYANT, S.L., PEMBERTON, D. \& NORTON, T.W., 1985: Mammals of the Upper Henty River region, western Tasmania. Pap. Proc. R. Soc. Tas. 119: 7-14.

TAYLOR, R.J. \& O'NE1LL, M.G., 1986: Composition of the bat (Chiroptera: Vespertilionidae) communities in Tasmanian forests. Aust. Mammal., 9: $125-130$.

THOMAS, O., 1915: Notes on the Genus Nyctophilus. Ann. Mag. Nat. Hist. ser. B, 15: 493-499.
TIDEMANN, C.R., 1982: Sex differences in seasonal changes of brown adipose tissue and activity of the Australian vespertilionid bat Eptesicus vulturnus. Aust. J. Zool., 30: 15-22.

TIDEMANN, C.R., 1986: Morphological variation in Australian and island populations of Gould's wattled bat, Chalinolobus gouldii (Gray) (Chiroptera: Vespertilionidae). Aust. J. Zool. 34: 503-514.

TIDEMANN, C.R. \& WOODSIDE, D.P., 1978: A collapsible bat trap and a comparison of results obtained with the trap and with mist-nets. Aust. Wildl. Res., 5: 355-362.

TROUGHTON, E. Le.G., 1941: FURRED ANIMALS OF AUSTRALIA. Angus and Robertson, Sydney.

STRAHAN, R., 1983: COMPLETE BOOK OF AUS TRALIAN MAMMALS. Angus and Robertson, Sydney.

VESTJENS, W.J.M. \& HALL, L.S., 1977: Stomach contents of forty-two species of bats from the Austraiasian region. Aust. Wildl. Res., 4: 25-35.

WOINARSKI, J., 1986: Sharing a small hollow by roosting bats and nesting forty-spotted pardalotes. Tasm. Nat., 84: 1.

YOUNG, R.A., 1979: Observations on parturition, litter size and foetal development at birth in the chocolate wattled bat, Chalinolobus morio (Vespertilionidae). Vict. Nat., 96: 90-91.

(accepted 23 March 1987) 